\title{
CZY BÓG MOŻE ISTNIEĆ BEZ BIEDNYCH?
}

DOI: http://dx.doi.org/10.12775/TiCz.2017.043

Właściwością typową tylko dla samego Boga jest przekraczanie nie tylko każdego dzieła ludzkiego, ale także każdej najznakomitszej utopii. Jakikolwiek projekt, który pragnie naśladować człowiek, powinien jednak jednocześnie być otwartym ku szukaniu jego przyczyn. Kiedy natomiast w historii następuje weryfikacja oraz obrona programów politycznych, ekonomicznych i społecznych, okazuje się, że kończyły się one często powstaniem trudnych do pokonania dramatów ubóstwa, biedy i zła osobowego oraz społecznego. Co więcej, jawiły się jako oferty z brakiem pozytywnych rozwiązań.

Wszystko to powinno mieć wartość także dla refleksji: jak bardzo potrzebne jest poszukiwanie coraz bardziej sprawiedliwego świata, w którym dramat ubóstwa będzie pokonany, m.in. wystarczalnością dóbr zaspokajających podstawowe potrzeby fizyczne i duchowe każdego człowieka. To wyzwanie tak natury, jak i kultury istot rozumnych, stworzonych na Boże obraz i podobieństwo (por. $\operatorname{Rdz} 1,27)^{1}$.

* Bp prof. dr hab. Andrzej Franciszek Dziuba od 2004 r. jest biskupem diecezjalnym w Łowiczu (ordynariusz@diecezja.lowicz.pl).

1 „Jest to rodzaj opcji, czyli specjalna forma pierwszeństwa w praktykowaniu miłości chrześcijańskiej, poświadczona przez całą Tradycję Kościoła. Odnosi się ona do 
Chodzi tutaj o prymat osoby, zarówno względem dóbr materialnych, jak i dobra wspólnego społeczności, w której ta osoba żyje. Wobec godności osoby jej przymioty, takie jak: stan posiadania czy utylitarne pojmowana aktualna przydatność dla społeczeństwa, mają charakter drugorzędny ${ }^{2}$.

\section{KOŚClÓł ZAANGAŻOWANY}

Każde osobowe zaangażowanie społeczne, w wymiarach ziemskiego czasu, nawet najbardziej pozytywne i twórcze, ma potrzebę odkupienia.

W świetle wiary solidarność zmierza do przekroczenia samej siebie, do nabrania wymiarów specyficznie chrześcijańskich całkowitej bezinteresowności, przebaczenia i pojednania. Wówczas bliźni jest nie tylko istotą ludzką z jej prawami i podstawową równością wobec wszystkich, ale staje się żywym obrazem Boga Ojca, odkupionym krwią Jezusa Chrystusa i poddanym stałemu działaniu Ducha Świętego. Winien być przeto kochany, nawet jeśli jest wrogiem, tą samą miłością, jaką miłuje go Bóg; trzeba być gotowym do poniesienia dla niego ofiary nawet najwyższej: «oddać życie za braci» (por. $1 \mathrm{~J} 3,16)$ ”.

Nie ma zatem interwencji Kościoła, która nie miałaby - oczywiście w jakimś sensie - uwarunkowań historycznych i geograficznych. „Stała obecność Chrystusa przy człowieku każdej epoki urzeczywistnia się w Jego ciele, którym jest Kościół. Dlatego Chrystus obiecał swoim uczniom Ducha Świętego, który miał im «przypomnieć» i wyjaśnić Jego

życia każdego chrześcijanina, które ma być naśladowaniem życia Chrystusa, ale stosuje się również do naszej społecznej odpowiedzialności, a zatem do stylu naszego życia, do decyzji, które trzeba stosownie podejmować w odniesieniu do własności i użytkowania dóbr" (Jan Paweł II, Encyklika Sollicitudo rei socialis, Città del Vaticano 1987, nr 42).

2 Por. Jan Paweł II, Encyklika Laborem exercens, Città del Vaticano 1981, nr $11-15$.

${ }^{3}$ Jan Paweł II, Encyklika Sollicitudo rei socialis, nr 40. Por. R. Tremblay, Radicati e fondati nel Figlio. Contributi per una morale di tipo filiale, Roma 1997, s. 125-140; E. Bosetti, Il Figlio e i figli di Dio. Etica filiale del Nuovo Testamento, „Rivista di teologia morale" 36 (2004), s. 218-230; R. Tremblay, L"'innalzamento" del Figlio, fulcro della vita morale, Roma 2001, s. 69-77. 
przykazania (por. J 14,26), i stać się źródłem nowego życia w świecie (por. J 3,5-8; Rz 8,1-13)"4.

W tej rzeczywistości pielgrzymującego Kościoła powinna zatem być obecna świadomość pewnego ryzyka i to akceptowanego. Zawsze jednak zjawisko to powinno być uświadomione i przyjmowane w kategoriach wyrównania domniemanych zobowiązań. Działania ku rozwojowi społeczności ludzkiej „nie mogą nie obejmować wielkich rzesz głodujących, żebrzących, bezdomnych, pozbawionych pomocy lekarskiej, a nade wszystko nie mających nadziei na lepszą przyszłość; nie można nie brać pod uwagę istnienia tych rzeczywistości" ${ }^{5}$.

$\mathrm{W}$ przeciwnym razie oznaczałoby to faworyzowanie zaproszenia, aby kontynuować osobowe zachowanie, tylko jako biernego, zewnętrznego obserwatora historii. Tymczasem na pytania stawiane przez chrześcijan Chrystusowi, On „odpowiada słowami Nowego Przymierza które powierzył swojemu Kościołowi (...). Dlatego odpowiedź Kościoła na pytania człowieka niesie w sobie mądrość i moc Chrystusa ukrzyżowanego, Prawdy, która nam się udziela"6.

Kościół znakomicie - ale niestety zewnętrznie tylko - spełniał często funkcję interpretatora w wielu radykalnych przewrotach społecznych. Tymczasem „aby umożliwić ludziom to «spotkanie» z Chrystusem, Bóg dał im swój Kościół. Istotnie, Kościół temu jednemu pragnie służyć, ażeby każdy człowiek mógł odnaleźć Chrystusa, aby Chrystus mógł z każdym iść przez życie" ${ }^{\prime}$. Gorzej było z pełnym zaangażowaniem, widzianym w kategoriach posługi wobec całego świata i każdego człowieka. To o mechanizmach wyzysku biednych i słabych przez bogatych i silnych,

${ }^{4}$ Jan Paweł II, Encyklika Veritatis splendor, Città del Vaticano 1993, nr 25. Por. A. Jankowski, Duch Ojca - Duch Syna, „Znak” 26 (1974), s. 1236-1238; H. Schlier, Zum Begriff des Geistes nach dem Johannesevangelium, w: Neutestamentliche Aufsatze für J. Schmid, Regensburg 1969, s. 233-239; A. Jankowski, Eschatologiczne znamiona posłannictwa Ducha Parakleta, w: Egzegeza Ewangelii św. Jana, red. F. Gryglewicz, Lublin 1976, s. $81-100$.

${ }^{5}$ Jan Paweł II, Encyklika Sollicitudo rei socialis, nr 42.

${ }^{6}$ Jan Paweł II, Encyklika Veritatis splendor, nr 117.

7 Jan Paweł II, Encyklika Veritatis splendor, nr 7. Por. Jan Paweł II, Encyklika Redemptor hominis, Città del Vaticano 1979, nr 13. 
o narastającym i umacniającym się rozwarstwieniu ekonomicznym i kulturowym ludzkości ${ }^{8}$.

\section{MOTYWEM MIKOŚĆ}

Jeśli to jest prawdą, po co zatem chrześcijaństwo kontynuowało utrzymywanie azylu dla ubogich? Po co widzieć ich obecność na ulicach i placach? Problem ubóstwa, mimo dynamicznego rozwoju technologicznego, nie tylko nie znika, ale coraz bardziej narasta, dotykając także coraz szersze grupy w krajach wysoko rozwiniętych ${ }^{9}$. Biedni, obdarowani naszą ofiarnością, nie stają się jednak automatycznie gwarancją naszego zbawienia. „Trzeba, aby w obliczu tej sytuacji chrześcijanin uczył się wyrażać swa wiarę w Chrystusa przez odczytywanie ukrytego wezwania, jakie On kieruje do niego ze świata ubóstwa"10.

Chrześcijanin nie otrzymał bowiem zadania podjęcia się obowiązków i posługi wobec biednych tylko po to, aby dzięki temu zbierać zasługi dla raju. Motywacja tego dzieła powinna czerpać swe źródło z miłości i nią się wyrażać. Faktycznie „poprzez tę opcję dajemy świadectwo o kształcie miłości Boga, o Jego opatrzności i miłosierdziu i w pewien sposób nadal rozsiewamy w dziejach ziarno Królestwa Bożego, które sam Jezus pozostawił w czasie swego ziemskiego życia, wychodząc naprzeciw tych, którzy zwracali się do Niego z wszelkimi potrzebami duchowymi i materialnymi" ${ }^{\prime 1}$. Kategorie przeliczników i stanu bilansu nie mają tu zastosowania, są wręcz wypaczeniem naszej funkcji wobec ubogich.

$\mathrm{Z}$ drugiej strony, najbardziej minimalnym przylgnięciem do ducha Ewangelii, tak fundamentalnym i nieprzemijającym, jest temat ubóstwa i ubogich. Ma on, upraszczając nieco, podwójny sens. Widać, iż w Bogu

8 Por. Jan Paweł II, Encyklika Sollicitudo rei socialis, nr 14, 43; Jan Paweł II, List apostolski Tertio millennio adveniente, Città del Vaticano 1994, nr 38; Jan Paweł II, Pokój wartością, która nie zna podziałów. Orędzie na Światowy Dzień Pokoju 1986, w: Orędzia Ojca Świętego Jana Pawła II, t. 1, Kraków 1998, s. 66-76.

9 Por. Jan Paweł II, Encyklika Sollicitudo rei socialis, nr 42.

10 Jan Paweł II, List apostolski Novo millennio ineunte, Città del Vaticano 2001, nr 50.

${ }^{11}$ Jan Paweł II, List apostolski Novo millennio ineunte, nr 49. 
Ojcu posłany Syn, Jezus Chrystus, dla objawienia siebie i dla zbawienia ludzi miał stać się ubogim i stosować środki ubogie ${ }^{12}$. „Odkupiciel człowieka Jezus Chrystus jest ośrodkiem wszechświata i historii” ${ }^{13}$ i On „zjednoczył się jakoś z każdym człowiekiem”"14.

Zatem w biednych, którzy zostali wybrani przez Chrystusa, manifestuje się przywilej zbawienia. Człowiek „musi niejako w Niego wejść z sobą samym, musi sobie przyswoić, zasymilować całą rzeczywistość Wcielenia i Odkupienia, aby siebie odnaleźć" ${ }^{15}$. Zbawienie bowiem sięga aż do newralgicznego punktu; jeśli biedni nie doświadczyli takiego zbawienia, dobra nowina jakby nie została jeszcze skutecznie ogłoszona. To jest ciągle stary i zarazem nowy "areopag” aktualizujący ważne problemy ludzkości, „na przykład zaangażowanie na rzecz pokoju, rozwoju i wyzwolenia ludów, praw człowieka i narodów, przede wszystkim mniejszości, działania na rzecz kobiety i dziecka, ochrony świata stworzonego" ${ }^{16}$.

\section{BRAMA BOGA}

W tej perspektywie powinny być na nowo przemyślane relacje, które łączą człowieka z Bogiem. Dobre postępowanie człowieka winno być widziane także jako skutek kształtowania obrazu Syna Bożego w człowieku. „W tym sensie życie moralne ma charakter głęboko «teleologiczny», ponieważ polega na świadomym przyporządkowaniu ludzkich czynów Bogu - najwyższemu dobru i ostatecznemu celowi (telos) człowieka"17. "Jesus domaga się, by Go naśladować i iść za Nim drogą miłości, która oddaje się bez reszty braciom dla miłości Boga: «To jest moje przykazanie,

12 „Jezus jest prawdziwą nowością przerastającą oczekiwania ludzi, a pozostanie nią na zawsze, przez wszystkie kolejne epoki dziejów. Wcielenie Syna Bożego oraz zbawienie, jakiego dokonał przez swoją śmierć i zmartwychwstanie, są zatem właściwym kryterium oceny rzeczywistości doczesnej i wszelkich zamysłów, które mają zapewnić człowiekowi życie coraz bardziej ludzkie" (Jan Paweł II, Bulla Incarnationis mysterium, „L'Osservatore Romano” 20 (1999) 1, nr 1).

13 Jan Paweł II, Encyklika Redemptor hominis, nr 1.

${ }^{14}$ Jan Paweł II, Encyklika Redemptor hominis, nr 13.

15 Jan Paweł II, Encyklika Redemptor hominis, nr 10.

${ }^{16}$ Jan Paweł II, Encyklika Redemptoris missio, Città del Vaticano 1990, nr 37.

17 Jan Paweł II, Encyklika Veritatis splendor, nr 73. 
abyście się wzajemnie miłowali, tak jak Ja was umiłowałem» (J 15,12). Owo «jak» domaga się naśladowania Jezusa, Jego miłości”18.

$\mathrm{Z}$ antropologicznego punktu widzenia „człowiek nie może żyć bez miłości. Człowiek pozostaje dla siebie istota niezrozumiałą, jego życie jest pozbawione sensu, jeśli nie objawi mu się Miłość, jeśli nie spotka się z Miłością, jeśli jej nie dotknie, i nie uczyni w jakiś sposób swoją, jeśli nie znajdzie w niej żywego uczestnictwa. I dlatego właśnie Chrystus-Odkupiciel, (...) «objawia w pełni człowieka samemu człowiekowi»"19. Bo „owocami miłości są radość, pokój i miłosierdzie. Miłość wymaga dobroci i upomnienia braterskiego; jest życzliwością; rodzi wzajemność; trwa bezinteresowna i hojna. Miłość jest przyjaźnią i komunią"20.

Chrześcijanin, który wspiera biednego, nie może jednak matematycznie zapisać tego na konto swoich zasług. Faktycznie bowiem uczynił tylko to, co jest jego obowiązkiem i powinnością ewangelizacyjnego świadectwa. „Tak więc zadaniem Kościoła jest dawać świadectwo miłości Chrystusa do ludzi, miłości gotowej do ofiary" ${ }^{21}$. Zresztą w szerszej perspektywie „Kościół przemienia dziejową sytuację nienawiści i przemocy w cywilizację miłości”22.

„Żywe zaniepokojenie losem ubogich, którzy - według wymownego sformułowania - są «ubogimi Pana», winno przekształcić się na wszystkich poziomach w konkretne czyny, aż do podjęcia decyzji dokonania szeregu potrzebnych reform"23. Faktycznie chrześcijanin, który nie idzie do ubogiego z miłością, nie może osiągnąć Boga czy nie ma wręcz prawa

18 Jan Paweł II, Encyklika Veritatis splendor, nr 20. Por. Jan Paweł II, Kto straci swe życie z powodu Mnie i Ewangelii, zachowa je, 28.10.1987, w: Katechezy Ojca Świętego Jana Pawła II. Jezus Chrystus, Kraków-Ząbki 1999, s. 164-169; R. Tremblay, Radicati e fondati nel Figlio. Contributi per una morale di tipo filiale, s. 125-140; tenże, Voi, luce del mondo... La vita morale dei Cristiani: Dio fra gli uomini, Bologna 2003, s. 57-64; tenże, „Ma io vi dico...” L'agire eccellente, specifico derlla morale cristiana, Bologna 2005, s. $167-184$.

19 Jan Paweł II, Encyklika Redemptor hominis, nr 10.

${ }^{20}$ KKK 1829.

${ }^{21}$ Jan Paweł II, Świadectwo miłości w Kościele - wspólnocie prorockiej, 3.06.1992, w: Katechezy Ojca Świętego Jana Pawła II. Kościót, Kraków-Ząbki 1999, s. 131.

${ }^{22}$ Jan Paweł II, Adhortacja apostolska Reconciliatio et paenitentie, Città del Vaticano 1984, nr 4.

${ }^{23}$ Jan Paweł II, Encyklika Sollicitudo rei socialis, nr 43. 
do wzywania Jego imienia. Ewangelicznie tylko ubogi może otworzyć bramy Boga. To zresztą jest wyborem samego Boga, ukazanym zwłaszcza w ubogim Chrystusie (por. 2 Kor 8,9). Jeśli wydaje się to dyskusyjne czy wątpliwe, to pozostanie tylko brakiem pełni świadomości wiary ${ }^{24}$.

Trzeba zatem mocno pamiętać, że „wiara posiada również wymiar moralny: jest źródłem zgodnego z nią życiowego zaangażowania i zarazem takiego zaangażowania się domaga. Obejmuje i wydoskonala przyjęcie i zachowywanie Bożych przykazań” ${ }^{25}$ (por. 1 J 1,56; 2,3-6). Przecież życie moralne wiary staje się „wyznaniem”, nie tylko wobec Boga, ale także przed ludźmi: staje się świadectwem ${ }^{26}$. Dlatego „żadne rozdarcie nie powinno zagrażać harmonii między wiarą a życiem" ${ }^{27}$. Brak przeżywania wiary w sposób konsekwentny i dojrzały prowadzi do postawy, która nie stanowi wiarygodnego wzoru do naśladowania. Jedność między wiarą i moralnością ukazywana jest „przez tych, którzy nie doceniają wagi powinności moralnych, jakie nakłada na nich Ewangelia (por. 1 Kor 5,9-13)"28.

${ }^{24}$ Por. S. Lyonnet, Liberte chretienne et loi de l'Esprit selon S. Paul, Rome 1954, s. 189-194; R. Schnackenburg, Lesistenza cristiana secondo il Nuovo Testamento, Modena 1971, s. 83-87; A. Hiebert, The Foundations of Paul's Ethics, w: Essays in Morality and Ethics. The Annual Publication of the College Theology Society, red. J. Gaffney, New York 1980, s. 50-62.

25 Jan Paweł II, Encyklika Veritatis splendor, nr 89.

26 „Trzeba ponownie odnaleźć i ukazać prawdziwe oblicze chrześcijańskiej wiary, która nie jest jedynie zbiorem tez wymagających przyjęcia i zatwierdzenia przez rozum. Jest natomiast poznaniem Chrystusa w wewnętrznym doświadczeniu, żywą pamięcią o Jego przykazaniach, prawdą, którą trzeba żyć. Słowo zresztą jest prawdziwie przyjęte dopiero wówczas, gdy wyraża się w czynach i urzeczywistnia w praktyce. Wiara to decyzja, która angażuje całą egzystencję. Jest spotkaniem, dialogiem, komunią miłości i życia między wierzącymi a Jezusem Chrystusem: Drogą, Prawdą i Życiem (por. J 14,6). Prowadzi ona do aktu zaufania i zawierzenia Chrystusowi i pozwala nam żyć tak, jak On żył (por. Ga 2,20), to znaczy miłując ponad wszystko Boga i braci” (Jan Paweł II, Encyklika Veritatis splendor, nr 88).

27 Jan Paweł II, Encyklika Veritatis splendor, nr 26.

${ }^{28}$ Jan Paweł II, Encyklika Veritatis splendor, nr 26. Por. H. U. von Balthasar, Nove tesi sulletica cristiana, w: J. Ratzinger, H. Schurmann, H. U. von Balthasar, Prospettive di morale cristiana. Sul problema del contenuto e del fondamento dellethos cristiano, Roma 1986, s. 64-68; M. Bordoni, La cristologia nell'orizzonte dello Spirito, Brescia 1995, s. 59-64; R. Schnackenburg, Nauka moralna Nowego Testamentu, Warszawa 1983, 


\section{BÓG WYZWALA}

Dają się wyróżnić dwa podstawowe wymiary biedy i ubóstwa. Pierwszy dotyczy wprost sfery materialnej, drugi - procesu marginalizacji całych grup społecznych, a nawet krajów i regionów świata ${ }^{29}$. W tym drugim wypadku mówi się o "nowych ubogich” ${ }^{30}$. Oba wymiary wzajemnie się przeplatają i warunkują, utrudniając, a niekiedy wręcz uniemożliwiając pokonanie trudności. Dopiero Chrystus objawił w pełni człowieka samemu człowiekowi, a to może owocować głęboką zadumą nad sobą samym ${ }^{31}$. Dla Chrystusa bliźnim jest każdy człowiek, w każdym bowiem człowieku Jezus nakazuje widzieć samego siebie (por. Mt 25,40) ${ }^{32}$.

W Nim człowieczeństwo osiąga swój najwyższy stopień istnienia. I jest to „decydujące wydarzenie we wszechświecie, wydarzenie, które odnawia stworzenie, przywraca wszechświatowi i człowiekowi Jego początkową chwałę Bożą. Człowiek zaś realizuje się w sposób prawdziwy, kiedy uczestniczy w życiu Boga" ${ }^{33}$. Nie ma tu zasadniczego znaczenia lokata opiekuńcza, społeczna, ekonomiczna albo rewolucyjna, którą można dość łatwo i nawet spektakularnie zrealizować wobec siebie i innych. Te zewnętrzne kategorie nie wystarczają, zwłaszcza gdy znaczone są tylko wymiarem ideologii. Tymczasem godność osobowa jest źródłem „współuczestnictwa i wzajemnej solidarności, bowiem dialog i komunia wywodzą się przede wszystkim z tego, kim ludzie «są», a dopiero wtórnie $\mathrm{z}$ tego, co «mają»" ${ }^{34}$.

s. 339-442; H.-D. Wendland, Etica del Nuovo Testamento, Brescia 1975, s. 106-109; J. Kudasiewicz, Cechy specyficzne etosu biblijnego, w: W nurcie zagadnień posoborowych, t. 14: Chrześcijańska duchowość, red. B. Bejze, Warszawa 1981, s. 83-86.

29 Por. Jan Paweł II, Encyklika Sollicitudo rei socialis, nr 42.

30 Por. Jan Paweł II, Przebacz, a zaznasz pokoju. Orędzie na Światowy Dzień Pokoju 1997, Città del Vaticano 1996, nr 3.

31 Por. Jan Paweł II, Encyklika Redemptor hominis, nr 10.

${ }^{32}$ Por. A. Feuillet, Le caractère universel du jugement et la charité sans frontières en Mt 25,31-46, „Nouvelle Revue Théologique” 102 (1980), s. 179-196; V. K. Agbanou, Le discours eschatologique de Matthieu 24-25: tradition et redaction, Paris 1983, s. 169-174; J. Gnilka, Il Vangelo di Matteo, t. 2, Brescia 1991, s. 533-554.

33 Papieski Komitet Obchodów Wielkiego Jubileuszu Roku 2000, Jezus Chrystus, jedyny Zbawiciel świata, wczoraj, dziś i na wieki, Katowice 2000, s. 40.

${ }^{34}$ Jan Paweł II, Adhortacja apostolska Christifideles laici, nr 37. 
Oczywiście, w tym samym czasie chrześcijanin nie może nie walczyć przeciw wszelkim formom ubóstwa, i to za pomocą najdoskonalszych środków, którymi dysponuje. Idzie tu także o działania o wymiarze społecznym. Prawdziwy rozwój człowieka ma charakter integralny, przyczynia się do wzrostu duchowego i materialnego ${ }^{35}$. Staje tutaj solidarność jako „mocna i trwała wola angażowania się na rzecz dobra wspólnego, czyli dobra wszystkich i każdego, wszyscy bowiem jesteśmy odpowiedzialni za wszystkich" 36 .

Z drugiej strony wskazuje się na niemoc organizacji międzynarodowych w zaprowadzaniu sprawiedliwego ładu, owocującą coraz to nowymi obszarami ludzkiego życia naznaczonego ubóstwem i biedą ${ }^{37}$. „Nie można też w zaangażowaniu na rzecz ubogich pomijać owej szczególnej formy ubóstwa, jaką jest pozbawienie osoby ludzkiej podstawowych praw"38. Jest to jednocześnie respekt wobec darmowego przykazania miłości, ale bez odrzucenia spotkania i odkrycia - zawsze bolesnego - osoby biednego, którego tylko Bóg może ostatecznie wyzwolić.

Trójjedyny Bóg ${ }^{39}$ : kochający i miłujący Ojciec, odnawiający przymierze z człowiekiem i obdarzający go na nowo swoją miłością oraz przywracający mu pierwotną godnośćc ${ }^{40}$; Syn ofiarujący się za ludzi i pokonujący grzech przez zbawcze dzieło - Mesjasz ${ }^{41}$, który „więźniom głosi wolność i uciśnionych odsyła wolnymi” (Łk 4,18; Iz 61,1-2); Duch Święty, który uwalnia „ze starych i nowych determinizmów”42 i „daje życie w Chrystusie Jezusie" (Rz 8,2) oraz, prowadząc człowieka, udziela wszelkich łask, który odkrywa i urzeczywistnia pełną miarę prawdziwej

35 Por. Jan Paweł II, Encyklika Sollicitudo rei socialis, nr 29.

${ }^{36}$ Jan Paweł II, Encyklika Sollicitudo rei socialis, nr 38.

37 Por. Jan Paweł II, Encyklika Sollicitudo rei socialis, nr 43; Jan Paweł II, Adhortacja apostolska Ecclesia in Africa, Città del Vaticano 1995, nr 44.

38 Jan Paweł II, Encyklika Sollicitudo rei socialis, nr 42.

39 Por. Jan Paweł II, Encyklika Dives in misericordia, Città del Vaticano 1980, nr 8.

40 Por. Jan Paweł II, Encyklika Veritatis splendor, nr 118; Jan Paweł II, Encyklika Dives in misericordia, nr 4.

${ }^{41}$ Por. Jan Paweł II, List apostolski Tertio millennio adveniente, nr 11; Jan Paweł II, Encyklika Veritatis splendor, nr 86.

${ }^{42}$ Jan Paweł II, Encyklika Dominum et Vivificantem, Città del Vaticano 1986, nr 60. 
wolności człowieka ${ }^{43}$, bo „gdzie jest Duch Pański - tam wolność” (2 Kor $3,17)^{44}$. Kościół niesie pomoc, „głosząc człowiekowi Boże zbawienie, ofiarowując mu i przekazując Boże życie za pośrednictwem sakramentów, nadając kierunek jego życiu przykazaniami miłości Boga i bliźniego”45.

\section{SERCE UBOGIEGO}

Kim jest zatem Bóg, aby Go znaleźć niezbędnym jest serce ubogiego? To „przez ubogich niejako sam Chrystus głośno woła o miłosierdzie swoich uczniów”46. „Chrystus został posłany przez Ojca, «aby ubogim nieść dobrą nowinę, aby uzdrawiać skruszonych w sercu» $(Ł k 4,18)$, «aby odszukać i zbawić to, co zginęło» (Łk 19,10); podobnie i Kościół otacza miłością wszystkich dotkniętych ludzką słabością, co więcej w ubogich i cierpiących odnajduje wizerunek swego ubogiego i cierpiącego Założyciela, stara się ulżyć im w niedoli i w nich usiłuje służyć Chrystusowi”"

Chrystus w swym paschalnym dziele zbawczym stał się biednym; oznacza to, że otworzył się na jedną z instancji najbardziej wymagających wobec naszego nawrócenia. Nawrócenie wymaga nieustannej świadomości zależności od Boga i przemijalności rzeczy ziemskich. Zakłada to gotowość słuchania słowa Bożego oraz udział w życiu sakramentalnym Kościoła. Pokutny wymiar życia chrześcijanina prowadzi go do postawy czuwania nad sobą, wyraża się zdolnością do wyrzeczeń, by mógł on przychodzić innym z pomocą ${ }^{48}$. Doświadczając grzechu i uświadamiając

${ }^{43}$ Por. Jan Paweł II, Encyklika Dominum et Vivificantem, nr 57-59.

${ }_{44}$ Por. R. Tremblay, Radicati e fondati nel Figlio. Contributi per una morale di tipo filiale, s. 151-155; tenże, Cristo e la morale in alcuni documenti del magistero, Roma 1996, s. 180-184; F. Gils, Désaltérés par l’unique Esprit, Paris 1982, s. 98-100, 164-170, 187-189; H.-D. Wendland, Etica del Nuovo Testamento, s. 65-69; J. Cambier, La liberté chrétienne selon saint Paul, „Lumiere et vie” 12 (1963), s. 23-31.

45 Jan Paweł II, Encyklika Centesimus annus, Città del Vaticano 1991, nr 55. Por. Jan Paweł II, Adhortacja apostolska Christifideles laici, Città del Vaticano 1988, nr 33-34.

${ }^{46}$ KDK 88.

47 KK 8. Por. P. Sequeri, Il tragico nellesistenza e la theologia crucis, „Teologia” 19 (1994), s. 311-339; H. Schurmann, Das Lukasevangelium, t. 1, Freiburg 1969, s. 229-231; R. Tremblay, L’,innalzamento” del Figlio, fulcro della vita morale, s. 98-107.

48 Por. Jan Paweł II, Adhortacja apostolska Christifideles laici, nr 30. 
sobie zniewolenie, człowiek pragnie wyzwolenia. Jest ono możliwe przez wiarę w moc Misterium Paschalnego Chrystusa ${ }^{49}$. Nawrócenie dotyczy nie tylko poszczególnych osób, ale ma swój wymiar społeczny, przemieniający wzajemne relacje między ludźmi ${ }^{50}$. Jeśli jednak biedni są tylko celem naszego zaangażowania społecznego, to są jednocześnie jedynie gwarancją naszej drogi widzianej jako ideologia ${ }^{51}$. „Jezus Chrystus rozpozna swoich wybranych po tym, co uczynili dla ubogich. Gdy «ubogim głosi się Ewangelię» (Mt 11,5), jest to znak obecności Chrystusa" ${ }^{32}$.

Jeśli natomiast przeciwnie - wychodzi się od nich, aby ponownie odczytał i przemienił nasze życie, wówczas Kościół i nasze osobowe odniesienie do Pana stają się zdolne do bycia czytelnym objawieniem oblicza zbawczego Boga. „Nasz Pan ostrzega nas, że zostaniemy od Niego oddzieleni, jeśli nie wyjdziemy naprzeciw ważnym potrzebom ubogich i maluczkich, którzy są Jego braćmi” ${ }^{53}$. „Droga Kościoła przebiega przez serce człowieka, tam bowiem jest owo ukryte miejsce zbawczego spotkania z Duchem Świętym, z Bogiem ukrytym"54.

Idzie tu o tego Boga, którego człowiek - bez świadomości posłanego ubogiego Syna - nie ma prawa sam wzywać. Idzie o tego Boga, który bez ubogich nie może być wzywanym przez sam Kościół. „Jezus Chrystus, «istniejąc w postaci Bożej, (...) ogołocił samego siebie, przyjąwszy postać sługi» (Flp 2,6) i ze względu na nas «będąc bogatym (...) stał się

49 Por. Jan Paweł II, Ja jestem $z$ wami aż do skończenia świata (por. Mt 28,20). Orędzie na Wielki Post 2000, „L'Osservatore Romano” 21(2000), nr 3.

${ }^{50}$ Por. Jan Paweł II, Adhortacja apostolska Reconciliatio et paenitentia, nr 18, 25.

${ }^{51}$ „Każdy wierzący człowiek (...) powinien być wobec świata świadkiem zmartwychwstania i życia Pana Jezusa i znakiem Boga żywego. Wszyscy razem i każdy z osobna mają żywić świat duchowymi owocami (por. Ga 5,22) i napełniać go takim duchem, jakim są ożywieni owi ubodzy, łagodni i wprowadzający pokój, których Pan nazwał w Ewangelii błogosławionymi (por. Mt 5,3-9)" (KK 38). Por. P. Remy, Foi chrétienne et morale, Paris 1973, s. 49-61; J. K. Nagórny, Teologiczna interpretacja moralności Nowego Przymierza, Lublin 1989, s. 335-345; R. Nixon, Fulfilling the Law: The Gospels and Acts, w: Law, Morality and the Bible. A Symposium, red. B. Kaye, G. Wenham, Dovners Grove 1978, s. 58-65; J.-F. Collange, De Jésus à Paul: L'etique du Nouveau Testament, Geneve 1980, s. 234-240.

${ }^{52}$ KKK 2443.

${ }^{53}$ KKK 1033.

${ }^{54}$ Jan Paweł II, Encyklika Dominum et Vivicantem, nr 67. 
ubogim» (2 Kor 8,9)”55. Wzorem „wyobraźni miłosierdzia” jest Chrystus, który obdarowuje nią. Ludzi - obdarowywał ich sobą. Stał się solidarny z ubogimi, stając po ich stronie. Natomiast „duch ubóstwa i miłosierdzia jest bowiem chwałą i świadectwem Kościoła Chrystusowego" ${ }^{56}$.

To jest najbardziej radykalna droga, którą Kościół, zgodnie ze swoim powołaniem, bezwzględnie powinien przejść. „Kościół temu jednemu pragnie służyć, ażeby każdy człowiek mógł odnaleźć Chrystusa, aby Chrystus mógł z każdym iść przez życie" ${ }^{57}$. Dzięki temu ma jedyną szansę, aby zachować własną identyczność i tożsamość. Jego transcendencja ostatecznie rodzi się tam, gdzie Bóg wybrał najwyższy stopień wcielenia i to w słabości ludzkiej. „W tajemnicy Wcielenia położone zostały podwaliny antropologii, która zdolna jest przekroczyć własne ograniczenia i sprzeczności, zmierzając ku samemu Bogu, a nawet więcej - ku «przebóstwieniu» poprzez wszczepienie w Chrystusa człowieka odkupionego, dopuszczonego do udziału w życiu trynitarnym" ${ }^{58}$. Ubóstwienie i bycie wśród ubogich urasta do rangi pełni Nowego Przymierza ${ }^{59}$.

Streszczenie. Bóg przekracza wszelkie ludzkie dzieła. Tu poszukiwanie pokonania dramatu ubóstwa. Każde zaangażowanie społeczne ma wymiar odkupieńczy. W Kościele nie zawsze miało to wymiar posługi wobec świata i konkretnego człowieka. Motywacja pomocy nie powinno być zbawienie, ale miłość i w niej się wyrażać. Jezus posłany jest jako Ubogi i i stosuje środki ubogie. W biednych manifestuje się przywilej zbawienia. Pomoc ubogim jest obowiązkiem chrześcijanina. Ubogi otwiera bramy Boga. Ideologia pomocy nie wystarcza. Choć chrześcijanin ma walczyć przeciw ubóstwu, ale zawsze chodzi o konkretnego ubogiego. W nim można znaleźć Boga. Przemienione własne życie może stać się obliczem zbawczego Boga. Bóg bez ubogich nie może być wzywany przez sam Kościół. Ubóstwo i bycie wśród ubogich urasta do rangi pełni Nowego Przymierza.

${ }^{55} \mathrm{KK} 8$.

${ }^{56}$ KDK 88.

57 Jan Paweł II, Encyklika Redemptor hominis, nr 13.

58 Jan Paweł II, List apostolski Novo millennio ineunte, nr 23.

59 „Wywyższony zaś na krzyżu i uwielbiony Pan Jezus wylał obiecanego Ducha, przez którego powołał i zgromadził w jedności wiary, nadziei i miłości lud Nowego przymierza, który jest Kościołem. Uczy o tym Apostoł: «Jedno jest Ciało i jeden Duch, bo też zostaliście wezwani do jednej nadziei, jaką daje wasze powołanie. Jedne jest Pan, jedna wiara, jeden chrzest» (Ef 4,4n). Albowiem «wy wszyscy, którzy zostaliście ochrzczeni w Chrystusie, przyoblekliście się w Chrystusa (...) Wszyscy bowiem jesteście kimś jednym w Chrystusie Jezusie» (Ga 3,27n)” (DE 2). 
Słowa kluczowe: ubóstwo; miłość; Kościół; wyzwolenie; Bóg; ubogi.

Abstract. Can God Exist Without the Poor? God is always greater than all human works. Man wishes to overcome the drama of poverty. Every social experiment also had a salvific dimension, but has not always served man or the entire world well. Not salvation but love itself should be the reason for bringing help to others. Jesus was sent as One who was poor and He used poor means. The privilege of salvation manifests itself in the poor ones. One duty of a Christian is to help others. The poor one opens up the gates of God. The ideology of violence is absolutely erroneous. Christians have to fight against poverty, but they always have to care for their poor neighbor who has a name, and in whom God Himself may be found. One's transformed life may become, for those helped, the face of God who brings salvation. Service to God is expressed not only in Church but also in service to the poor. Alleviating poverty and being among the poor fulfills the New Covenant.

Key words: poverty; love; Church; liberation; God; poor.

\section{BIBLIOGRAFlA}

Agbanou, V. K., Le discours eschatologique de Matthieu 24-25: tradition et redaction, Paris 1983.

Balthasar von, H. U., Nove tesi sulletica cristiana, w: J. Ratzinger, H. Schurmann, H. U. von Balthasar, Prospettive di morale cristiana. Sul problema del contenuto e del fondamento dellethos cristiano, Roma 1986, s. 59-79.

Bordoni, M., La cristologia nellorizzonte dello Spirito, Brescia 1995.

Bosetti, E., Il Figlio e i figli di Dio. Etica filiale del Nuovo Testamento, „Rivista di teologia morale" 36 (2004), s. 218-230.

Cambier, J., La liberté chrétienne selon saint Paul, „Lumiere et vie” 12 (1963), s. 23-31.

Collange, J-.F., De Jésus à Paul: L'etique du Nouveau Testament, Geneve 1980. Feuillet, A., Le caractère universel du jugement et la charité sans frontières en Mt 25,31-46, „Nouvelle revue théologique” 102 (1980), s. 179-196.

Gnilka, J., Il Vangelo di Matteo, t. 2, Brescia 1991.

Hiebert, A., The Foundations of Paul's Ethics, w: Essays in Morality and Ethics. The Annual Publication of the College Theology Society, red. J. Gaffney, New York 1980, s. $50-62$.

Jan Paweł II, Adhortacja apostolska Christifideles laici, Città del Vaticano 1988.

Jan Paweł II, Adhortacja apostolska Ecclesia in Africa, Città del Vaticano 1995.

Jan Paweł II, Adhortacja apostolska Reconciliatio et paenitentie, Città del Vaticano 1984. Jan Paweł II, Bulla Incarnationis mysterium, „L'Osservatore Romano” 20 (1999) 1, s. 3-12. Jan Paweł II, Encyklika Centesimus annus, Città del Vaticano 1991. 
Jan Paweł II, Encyklika Dominum and Vivificantem, Città del Vaticano 1986.

Jan Paweł II, Encyklika Laborem exercens, Città del Vaticano 1981.

Jan Paweł II, Encyklika Redemptor hominis, Città del Vaticano 1979.

Jan Paweł II, Encyklika Redemptoris missio, Città del Vaticano 1990.

Jan Paweł II, Encyklika Sollicitudo rei socialis, Città del Vaticano 1987.

Jan Paweł II, Encyklika Veritatis splendor, Città del Vaticano 1993.

Jan Paweł II, Ja jestem $z$ wami aż do skończenia świata (por. Mt 28,20). Orędzie na Wielki Post 2000, „L'Osservatore Romano” 21 (2000) 3, s. 4-6.

Jan Paweł II, Kto straci swe życie z powodu Mnie i Ewangelii, zachowa je, 28.10.1987, w: Katechezy Ojca Świętego Jana Pawła II. Jezus Chrystus, Kraków-Ząbki 1999, s. $164-169$.

Jan Paweł II, List apostolski Novo millennio ineunte, Città del Vaticano 2001.

Jan Paweł II, List apostolski Tertio millennio adveniente, Città del Vaticano 1994.

Jan Paweł II, Pokój wartością, która nie zna podziałów. Orędzie na Światowy Dzień Pokoju 1986, w: Orędzia Ojca Świętego Jana Pawła II, t. 1, Kraków 1998, s. 66-76.

Jan Paweł II, Przebacz, a zaznasz pokoju. Orędzie na Światowy Dzień Pokoju 1997, Città del Vaticano 1996.

Jan Paweł II, Świadectwo miłości w Kościele - wspólnocie prorockiej, 3.06.1992, w: Katechezy Ojca Świętego Jana Pawła II. Kościót, Kraków-Ząbki 1999, s. 130-133.

Jankowski, A., Duch Ojca - Duch Syna, „Znak” 26 (1974), s. 1236-1238.

Jankowski, A., Eschatologiczne znamiona posłannictwa Ducha Parakleta, w: Egzegeza Ewangelii św. Jana, red. F. Gryglewicz, Lublin 1976, s. 81-100.

Kudasiewicz, J., Cechy specyficzne etosu biblijnego, w: W nurcie zagadnień posoborowych, t. 14: Chrześcijańska duchowość, red. B. Bejze, Warszawa 1981, s. 83-86.

Lyonnet, S., Liberte chrétienne et loi de l'Esprit selon S. Paul, Rome 1954.

Nagórny, J. K., Teologiczna interpretacja moralności Nowego Przymierza, Lublin 1989.

Nixon, R., Fulfilling the Law: The Gospels and Acts, w: Law, Morality and the Bible. A Symposium, red. B. Kaye, G. Wenham, Dovners Grove 1978, s. 58-65.

Papieski Komitet Obchodów Wielkiego Jubileuszu Roku 2000, Jezus Chrystus, jedyny Zbawiciel świata, wczoraj, dziś i na wieki, Katowice 2000.

Remy, P., Foi chrétienne et morale, Paris 1973.

Schlier, H., Zum Begriff des Geistes nach dem Johannesevangelium, w: Neutestamentliche Aufsatze für J. Schmid, Regensburg 1969.

Schnackenburg, R., Lesistenza cristiana secondo il Nuovo Testamento, Modena 1971.

Schnackenburg, R., Nauka moralna Nowego Testamentu, Warszawa 1983.

Schurmann, H., Das Lukasevangelium, t. 1, Freiburg 1969.

Sequeri, P., Il tragico nellesistenza e la theologia crucis, „Teologia” 19 (1994), s. 311-339 .

Tremblay, R., „Ma io vi dico...” L'agire eccellente, specifico della morale cristiana, Bologna 2005.

Tremblay, R., L’,innalzamento” del Figlio, fulcro della vita morale, Roma 2001. 
Tremblay, R., Radicati e fondati nel Figlio. Contributi per una morale di tipo filiale, Roma 1997.

Tremblay, R., Voi, luce del mondo... La vita morale dei Cristiani: Dio fra gli uomini, Bologna 2003.

Wendland, H.-D., Etica del Nuovo Testamento, Brescia 1975. 